Journal of the Scholarship of Teaching and Learning, Vol. 20, No. 2, October 2020, pp. 15-30.

doi: 10.14434/josotl.v20i2.25640

\title{
Defining Science Literacy in General Education Courses for Undergraduate Non-Science Majors
}

\author{
Eleanor V.H. Vandegrift \\ University of Oregon \\ ellyvan@uoregon.edu \\ Ronald A. Beghetto \\ Arizona State University \\ Judith S. Eisen \\ University of Oregon \\ Peter M. O'Day \\ University of Oregon \\ Michael G. Raymer \\ University of Oregon \\ Nicola C. Barber \\ University of Oregon
}

\begin{abstract}
This article describes a project focused on identifying science instructors' conceptions of science literacy and using these conceptions to develop a brief science literacy student self-assessment (SCILIT). We present the rationale and process we used to elicit instructors' conceptions of science literacy, crafted in a meaningful way with input by faculty and graduate student science experts. Next, we explain how we developed a novel student SCILIT self-assessment based on those expert conceptions. We describe our initial efforts using SCILIT in undergraduate general education science courses to explore students' self-perceived science literacy. We discuss the use of SCILIT self-assessment to assess potential progression of students' self-rated science literacy over the course of an academic term, and how this student self-assessment relates to instructor ratings of academic proficiency and science literacy. Finally, we reflect on the use of SCILIT self-assessment to guide instruction and assessment in general education science courses for non-science majors.
\end{abstract}

Keywords: science literacy, undergraduates, general education, non-science majors

\section{Introduction}

Although there is an extensive literature about science literacy and consensus on the importance of building a scientifically literate populace, it is difficult to identify a single, adequate definition and an instrument to measure undergraduate student science literacy across disciplines (National Academies of Sciences, Engineering, and Medicine, 2016). The ability of higher education instructors to improve the impact of teaching practices to support student gains in science literacy and reduce students' scientific misconceptions rests on instructors' ability to monitor and clarify students' science literacy (Singer, Nielsen, \& Schweingruber, 2012). However, even with the extensive literature about science literacy, faculty within or across institutions, and especially faculty in a variety of scientific disciplines, may lack consensus on a single definition, which could result in the term "science literacy" losing 
meaning for instructors who want to promote development of students' general understanding of science. Indeed, a serious problem facing higher education instructors is the difficulty in finding readymade definitions and assessments general enough to be used in courses representing a range of science disciplines and yet specific enough to be aligned with instructors' conceptions of science literacy (Laugksch, 2000). Therefore, to drive general education reform focused on improving student science literacy within one program at our university, we turned to our affiliated faculty experts to develop a locally agreed upon concept of science literacy that could be used as a guide for setting course learning goals and for student self-assessment, and for comparisons with faculty assessment of student learning. Here, we explore relevant science literacy literature that has guided our project, in which we designed, developed, and implemented a new science literacy student self-assessment instrument (SCILIT) for students at our university. We had three interrelated goals: 1) define science literacy across scientific disciplines using experts' implicit conceptions of science literacy; 2) design and develop an instrument to measure student self-assessed science literacy across scientific disciplines in general education non-science majors courses; and 3) measure student self-assessment and gains in science literacy in general education non-science majors courses.

The need for higher education to support broadening of science literacy and improved scientific awareness of the educated public is increasingly important as biomedical, scientific, and technological advances accelerate in our world. There is a well-documented need for enhancing training in Science, Technology, Engineering, and Mathematics (STEM) (Olson \& Riordan, 2012) and a demand for higher education to develop students' skills for 21st century employment, including scientific knowledge and skills transferrable from classrooms to ever-changing careers (Pellegrino \& Hilton, 2012; Singer, et al. 2012). However, educators, scientists, and industry leaders are concerned that, even in industrialized nations, science literacy falls far short of meeting 21 st century needs (Gross, 2006; Kohut, Keeter, Doherty, \& Dimock, 2009; Miller, 2004; National Science Board, 2012; Scearce, 2007). Reasons behind this situation are undoubtedly complex and have been the subject of many studies (Adams \& Pegg, 2012; Bryant, Kastrup, Udo, Hislop, Shefner, \& Mallow, 2012; Falk \& Needham, 2013; National Center for Education Statistics, 2012).

There is a vast literature describing definitions and assessments of science literacy, including measures for K-12 science and engineering (National Research Council, 2013; PISA, 2006; Schweingruber, Keller, \& Quinn, 2012; Stage, Asturias, Cheuk, Daro, \& Hampton, 2013), contentand discipline-specific assessments for college-level students (Gormally, Brickman, \& Lutz, 2012; Jin \& Bierma, 2013), and assessments for the general public (Steel, Smith, Opsommer, Curiel, \& WarnerSteel, 2005). However, few measures of science literacy can be applied across scientific disciplines for undergraduate, non-science majors because, even with expanded work on key areas that constitute science literacy, such as problem-solving ability (Singer et al., 2012), there is no consensus on the definition of science literacy among higher education faculty (Scearce, 2007).

Arriving at a definition of science literacy that can be applied across scientific disciplines in non-science-major's courses is a step in developing a measure that science instructors from different disciplines can use to assess students' science literacy. This is challenging given that published definitions of science literacy vary widely (National Academies of Sciences, Engineering, and Medicine, 2016) and a diversity of researchers have worked for many years to develop definitions of science literacy that resonate with particular groups. For example, some conceptions emphasize the importance of content knowledge or ability to read and understand popular media (Miller, 2006; National Research Council, 1996; Parkinson \& Adendorff, 2004), some stress the ability to appreciate and communicate science (Gräber, Erdmann, \& Schlieker, 2001; Holbrook \& Rannikmae, 2009; Lee \& Roth, 2003), and others highlight skills needed to evaluate evidence, apply scientific method, or actively participate in civic life (Deboer, 2000; Gräber et al., 2001; Hazen, 2002; Holbrook \& Rannikmae, 2009; Hurd, 1998; Lee \& Roth, 2003; Schweingruber et al., 2012). More generally, for

Journal of the Scholarship of Teaching and Learning, Vol. 20, No. 2, October 2020. josotl.indiana.edu 
long-term science literacy, it has been suggested that students learn how to solve "ill-defined" problems that simulate scientific discovery and "well-defined" problems with clear solutions (Singer et al., 2012, p. 76). Often multiple elements and components of science literacy are combined into a single definition.

Other conceptions of science literacy emphasize content knowledge or are more narrowly focused within a specific discipline, for example, physics literacy (Hobson, 2003), ocean literacy (Steel et al., 2005), chemical literacy (Witte \& Beers, 2003), biological literacy (Brewer \& Smith, 2011; Coil, Wenderoth, Cunningham, \& Dirks, 2010; Gormally et al., 2012), climate literacy (McCaffrey \& Buhr, 2008), or environmental literacy (Hungerford, 2009). A recent Science Literacy Concept Inventory is largely framed around higher education students' reasoning and understanding of the nature of science (Nuhfer et al., 2016). Still other conceptions focus on promoting science literacy in specific contexts to specific populations: K-12 students (Adams \& Pegg, 2012; Deboer, 2000; Hurd, 1998; PISA, 2006; Schweingruber et al., 2012), individual cultures or countries (Choi, Lee, Shin, Kim, \& Krajcik, 2011; Jack, Lin, \& Yore, 2014), place-based contexts (Birmingham \& Barton, 2013; Goldsmith et al., 2013), general publics (Falk \& Needham, 2013; Lee \& Roth, 2003), and college-level students (Coil et al., 2010; Gormally et al., 2012; Jin \& Bierma, 2013; Karsai \& Kampis, 2010; Porter et al., 2010).

Given the wide range of available science literacy definitions and contexts, we found it useful to recognize that our science instructors, who are experts in their respective fields, already hold implicit conceptions of science literacy that they apply when teaching science courses for non-science majors. Indeed, implicit conceptions "already exist, in some form, in people's heads" (Sternberg, 1985 p. 608). An important advantage of eliciting implicit conceptions from expert instructors is that the validity of elicited conceptions is inherent in the domain knowledge of experts themselves. Indeed, as Baer and McKool (2009) have argued, when one has access to experts, one need not use some externally developed "test, rubric, or some other device to approximate the judgments of experts" (p. 5). Rather, one can go directly to the "most valid yardstick" - experts themselves. We therefore looked to elicit a definition of science literacy using input from instructors in different disciplines within our program that would best operate across these diverse science disciplines. We further reasoned that with such varying (and conflicting) definitions of science literacy across the literature, faculty in our program would be more likely to "buy-in" to a definition of science literacy that was built upon their implicit conceptions and teaching expertise and developed specifically for this local context.

Based on our elicited definition we developed a student science literacy self-assessment that probed the characteristics and behaviors associated with science literacy rather than any specific content knowledge. Students' perception of their own science literacy represents a specific type of self-belief. Self-beliefs play an important role in developing one's competence - be it in science or some other domain. Indeed, ability alone is insufficient when it comes to deepening one's understanding and persistence in learning (Bandura, 1997; Beghetto \& Baxter, 2012). As Buehl \& Alexander (2005) have succinctly stated, "students' beliefs matter" (p. 723). They matter because when students hold positive beliefs about their ability to learn science, they are more likely to value science, engage in classroom learning, and persist in subsequent science learning (Duschl, Schweingruber, \& Shouse, 2007).

\section{Context and Goals of Our Project}

Our project was carried out in the context of a multidisciplinary general education science program, launched in 2010 with extramural support, at a public research university in the U.S. Pacific Northwest. A program goal is to increase students' science literacy using evidence-based teaching practices, known to improve student learning, by incorporating these practices into the development and teaching of general education courses for non-science majors in astronomy, biology, chemistry, geology, and

Journal of the Scholarship of Teaching and Learning, Vol. 20, No. 2, October 2020. josotl.indiana.edu 
physics (Freeman, et al., 2014). All students at our university are required to take four general education science courses as part of a liberal arts distribution requirement. The science courses in our program were designed to place complex, discipline-specific scientific concepts within a framework relevant to non-science majors. Courses in our study were taught by teams of undergraduate science majors, science graduate students, and science department affiliated faculty, all of whom had at least initial exposure and some significant training in evidence-based, student-centered teaching methodologies (e.g., Handelsman, Miller \& Pfund, 2007).

Affiliated faculty had a shared goal of increasing students' science literacy by supporting students' comfort with and ability to be conversant with scientific thinking. However, consistent with previous studies, we discovered that language used by affiliated faculty from different disciplines to explain their science was not automatically transferrable between disciplines (Marder, 2013). Given that affiliated faculty had a variety of discipline-specific ideas about elements contributing to science literacy, a key aim of our project was to establish an agreed upon conception of science literacy that could be used in program courses across disciplines to guide instruction and assess student learning. To this end, we employed an exploratory design with convenience samples with courses taught by instructors affiliated with the program and students enrolled in their courses.

More specifically we had three interrelated goals. First, we endeavored to define our science instructors' conceptions of science literacy by having affiliated faculty and graduate student instructors describe behaviors that they consider as evidence of students' science literacy. Next, we aimed to discover agreement amongst affiliated faculty and graduate student instructors regarding the most important of these behaviors, so we could develop a brief science literacy student self-assessment (SCILIT). Finally, we used SCILIT to explore our students' self-rated conceptions of science literacy in program affiliated undergraduate science courses designed for non-science majors to determine whether we could measure student self-assessed gains in science literacy during a term in science courses at our university and meaningfully compare students' self-assessments to faculty assessment of such gains in a diversity of science courses.

\section{Goal 1: Define Science Literacy Across Scientific Disciplines}

To attain our first goal, we elicited behavioral characteristics of science literacy from a group of 13 affiliated faculty and senior graduate students - our identified experts. Members of this initial group represented biology, chemistry, geology, and physics departments and each had prior engagement with relevant science education literature through a weekly science education journal club and workshops (e.g. Handelsman et al., 2007; Brewer \& Smith, 2011). All of the graduate students and faculty were co-teaching or co-developing program affiliated courses with an expressed goal of improving student science literacy. Using a classical approach similar to previous researchers (Lim, Plucker, \& Im, 2002; MacKinnon, 1964; Sternberg, 1985), we utilized an online survey to ask respondents to "list as many behaviors characteristic of Science Literacy" as they wished to share. The project team compiled respondents' raw descriptions, eliminated or combined any duplicate descriptions, corrected misspellings, and clarified phrasing on a few descriptions.

The resulting list of initial behavioral characteristics included 48 candidate descriptors of science literacy (Table 1). Characteristics where quite varied - ranging from "understands science as presented in popular media (e.g., at level of New York Times)" to "confident in ability to challenge the ideas of an expert source."

Journal of the Scholarship of Teaching and Learning, Vol. 20, No. 2, October 2020. josotl.indiana.edu 
Table 1. Initial science literacy characteristics

Science Literacy Behavioral Characteristics in alphabetical order as determined by faculty and graduate student experts $(n=13)$ from an online survey.

1. Acts on models only within their realms of validity

3. Appreciates science and its role and relevance in everyday life

5. Approaches societal issues from skeptical and critically reasoned perspective

7. Asks for evidence supporting an argument

9. Aware of common societal issues that might be addressed by application of skeptical and critically reasoned perspective

11. Awareness of scientific milestones

13. Can access the available information on a topic of interest, and judge the quality of the information

15. Can apply quantitative thinking

17. Can confidently talk about various science-related topics

19. Can consider contradictory models when sufficient evidence for falsification of one or more models is not available.

21. Can critique claims and make an informed decision.

23. Can find, read, and understand media covering scientific topics

25. Can read and understand graphs and charts related to scientific information, especially as portrayed in the media or popular scientific press (e.g. Scientific American or Discover Magazine)

27. Can separate credible scientific information from opinion, conjecture, fabrication, and embellishments in advertisement

29. Confident in ability to challenge the ideas of an expert source.

31. Curious about the world around them
2. Objectively assesses the positions of others

4. Opposes those who discourage scientifically literate behavior

6. Reads, listens to, or watches media presentations related to science

8. Reconsiders previous conclusions with new information

10. Rejects unsupported or untested claims

12. Seeks appropriate scientificallysupported medical treatments

14. Seeks out good information upon which to base decisions and opinions

16. Self-critical (of own world-view)

18. Skeptical of claims presented as general truths

20. Tolerates uncertainty

22. Understand how and why people misrepresent scientific information (e.g. for person or political gain)

24. Understands distinction between scientific and non-scientific questions

26. Understands how questions can be pursued scientifically

28. Understands how science works (e.g., the "process" of science, how scientists ask and answer questions using the scientific method).

30. Understands how technological advances rest on basic scientific discoveries

32. Understands of how controversies may arise in science and the types of 
33. Encourages others to be scientifically literate

35. Enjoys talking about or thinking about science

37. Expresses social and political positions that are informed by scientific knowledge and reasoning

39. Identifies assumptions

41. Knows how to search for credible information about science

43. Less susceptibility to fallacies in logic

45. Maintains an ongoing interest in natural phenomena

47. Makes observations studies that might be used to resolve them

34. Understands science as presented in popular media (e.g., at level of New York Times)

36. Understands some of the scientific issues that are especially important to society (energy and climate, biotechnology, genomics)

38. Understands statistics and other manipulations of data

40. Understands the difference between data that show a correlation and data that result from an experiment designed to test causality

42. Understands the difference between deductive (e.g. logical/mathematical), inductive (e.g. scientific), and assertive (e.g. moral) "truths"

44. Understands the process for generating and experimentally validating scientific models

46. Understands where scientific data comes from

48. Willing to experiment when confronted with a problem

\section{Goal 2: Design and Develop an Instrument to Measure Student Self-Assessed Science Literacy Across Scientific Disciplines}

To focus and narrow the list displayed in Table 1, we asked affiliated faculty and graduate students to rate the science literacy behaviors they believed were most important in building students' science literacy. This approach represents a modified form of the "Delphi method" (Dalkey \& Helmer, 1963; Osborne, Simon, \& Collins, 2003), which involves establishing consensus on the most important items to reduce the total number of items by having a group of experts evaluate the individually generated items.

To this end, we had a larger, though partially overlapping, group of 29 science affiliated faculty and graduate students use an online survey to rate the importance of each of the 48 behavioral characteristics. This group included participants who were affiliated with the program (e.g., teaching affiliated courses, participating in science education journal club) representing biology, chemistry, geology, and physics disciplines. We asked participants to rate how important they thought it was for a scientifically literate, non-science major undergraduate to be able to demonstrate each of the characteristics using a 5 -point rating scale $(1=$ not at all important; $5=$ very important). 
We classified respondents' mean ratings ${ }^{1}$ of the characteristics into high and low importance groups using percentile rank function in the Statistical Package for the Social Sciences (SPSS, v. 21). This allowed us to develop a shorter consensus list by reducing the initial list to 25 characteristics with an average rating in the top $50^{\text {th }}$ percentile (Table 2 ).

Table 2. Twenty-five science literacy characteristics

Behaviors determined by experts $(n=29)$ to be most important for non-science majors to be scientifically literate. The 25 Characteristics listed in this table had mean ratings in the top $50^{\text {th }}$ percentile.

Description

1. Can separate credible scientific information from opinion, conjecture, fabrication, and embellishments in advertisement

2. Understands science as presented in popular media (e.g., at level of New York Times)

3. Reconsiders previous conclusions with new information

4. Understand how and why people misrepresent scientific information (e.g. for person or political gain)

5. Can critique claims and make an informed decision.

6. Less susceptibility to fallacies in logic

7. Aware of common societal issues that might be addressed by application of skeptical and critically reasoned perspective

8. Can read and understand graphs and charts related to scientific information, especially as portrayed in the media or popular scientific press (e.g. Scientific American or Discover Magazine)

9. Seeks out good information upon which to base decisions and opinions

10. Asks for evidence supporting an argument

11. Skeptical of claims presented as general truths

12. Understands distinction between scientific and non-scientific questions

13. Understands some of the scientific issues that are especially important to society (energy and climate, biotechnology, genomics)

14. Approaches societal issues from skeptical and critically reasoned perspective

15. Understands how science works (e.g., the "process" of science, how scientists ask and answer questions using the scientific method).

16. Objectively assesses the positions of others

17. Identifies assumptions

18. Appreciates science and its role and relevance in everyday life

19. Self-critical (of own world-view)

20. Understands the difference between data that show a correlation and data that result from an experiment designed to test causality
Mean SD

$4.45 \quad 69$

$4.45 \quad .63$

\begin{tabular}{ll}
$4.45 \quad .51$ \\
\hline
\end{tabular}

$4.45 \quad .78$

\begin{tabular}{ll}
$4.41 \quad .73$ \\
\hline
\end{tabular}

$4.41 \quad .69$

$4.34 \quad .77$

$4.34 \quad .72$

$4.31 \quad .66$

$4.31 \quad .60$

$4.31 \quad .85$

$4.28 \quad .70$

$4.28 \quad .75$

$4.28 \quad .80$

$4.24 \quad .79$

$4.24 \quad .69$

$4.24 \quad .74$

$4.24 \quad .83$

$4.21 \quad .68$

$4.18 \quad .91$

\footnotetext{
${ }^{1}$ We acknowledge that researchers have provided cautions and recommendations (e.g., use numerical response formats, use at least five categories of numerical responses, use aggregate rating scales) when treating data from such scales as continuous data for analysis (see Harpe, 2016). The rating scales of the SCILIT items and our treatment of these data as continuous in our analysis align with these general recommendations. That said, we recognize that some readers may view this as a limitation.
}

Journal of the Scholarship of Teaching and Learning, Vol. 20, No. 2, October 2020. josotl.indiana.edu 
21. Can access the available information on a topic of interest, and judge the quality of the information

22. Understands how technological advances rest on basic scientific discoveries

23. Knows how to search for credible information about science

24. Tolerates uncertainty

25. Rejects unsupported or untested claims

$\begin{array}{ll}4.14 & .74 \\ 4.10 & .72 \\ & \\ & \\ 4.10 & .77 \\ 4.07 & .65 \\ 4.07 & .96\end{array}$

Having identified 25 characteristics judged to be most important for science literacy by our larger set of experts, we then modified descriptions into first person so they could be used as a science literacy student self-assessment (SCILIT) (e.g., "I can tolerate uncertainty" or "I can identify assumptions"), which could be rated using a five-point agreement scale ( 1 = strongly disagree; $5=$ strongly agree). Given that we wanted to develop a brief scale, we endeavored to further reduce the 25 items into a shorter student self-assessment that would be easier for instructors to use with students.

To this end, we asked our affiliated faculty to have students enrolled in their general education science courses rate themselves on the 25 items. We collected data from 258 students across all four program-affiliated courses in winter 2013 (two interdisciplinary courses: chemistry/physics and biology/chemistry, and two single subject courses: biology and astronomy). These courses were part of the regular general education science offerings of the academic departments and were affiliated with the program through the training and mentoring offered to faculty, graduate student, and undergraduate teaching assistants. Almost two-thirds of respondents $(n=164 ; 63.6 \%)$ reported their gender as female and slightly more than two-thirds $(n=173 ; 67.1 \%)$ reported their race/ethnicity as white or Caucasian. Respondents represented a broad range of majors and areas of interest (including education, business, art history, science, Japanese language, as well as students undeclared in a major). The most frequent academic major or primary area of interest reported was psychology $(\mathrm{n}=87$; $33.7 \%$ ). The student self-assessment data were analyzed using principal component analysis (PCA) to explore whether we could identify a smaller number of items that were still representative of, and highly correlated with, the 25 items. PCA is a technique used by researchers to reduce multiple variables into smaller components. PCA is a widely used and adaptive exploratory method, because it is not constrained by typical assumptions of inferential statistical techniques and thereby can be used by researchers for the descriptive analysis of various types of quantitative data across a wide variety of situations (see Jolliffe \& Cadima, 2016). Given the flexibility of this approach, we determined that it was an appropriate tool to use to explore the dimensionality of students' responses on the 25 items.

Prior to conducting PCA, we carried out "parallel analysis" (O'Connor, 2000) to determine the number of components to keep from the total data set. This analysis indicated extraction of one component constituted from the student response data on the 25 science literacy items. To identify a core set of characteristics most representative of the overall science literacy component, we examined extracted communalities (which ranged from 0.11 to 0.53 ). We dropped items with communalities below 0.40 , because variance of those items was not well-accounted for by the science literacy component (Costello \& Osborne, 2005). This resulted in a total of eight retained SCILIT characteristics (Table 3). The resulting eight items represented a unidimensional component, accounting for $48.9 \%$ of variance. The eight items also demonstrated a high level of internal consistency $(\alpha=0.85)$, and use the same five-point agreement scale $(1=$ strongly disagree; $5=$ strongly agree) that was strongly correlated with the 25-item version $(r=0.93, p<0.001)$. These analyses suggest that the eight items adequately represent content of the 25-item list of SCILIT characteristics and could be used as a more parsimonious scale of science literacy self-assessment recognized by both instructors and students in our program study as representing science literacy.

Journal of the Scholarship of Teaching and Learning, Vol. 20, No. 2, October 2020. josotl.indiana.edu 
Table 3. SCILIT Behaviors for Student Self-Assessment Instrument

Retained science literacy items (SCILIT behaviors) based on principle component analysis. Items listed by size of component loading Coefficients calculated after listwise deletion of missing values. $(n=249)$.

Item

1. I can critique claims and make an informed decision

2. I can separate credible scientific information from opinion, conjecture, fabrication, and embellishments in advertisement

3. I seek out good information upon which to base decisions and opinions

4. I can identify assumptions

5. I approach societal issues from skeptical and critically reasoned perspective

6. I understand how science works (e.g., the "process" of science, how scientists ask and answer questions using the scientific method).

7. I am aware of common societal issues that might be addressed by application of skeptical and critically reasoned perspective

8. I understand science as presented in popular media (e.g., at level of New York Times)

$\begin{array}{cc}\begin{array}{c}\text { Component } \\ \text { loading }\end{array} & \begin{array}{c}\text { Item-total } \\ \text { correlation }\end{array} \\ .755 & .65 \\ .750 & .65\end{array}$

.737

$.674 \quad .56$

$.673 \quad .56$

.671

.56

.668

.55

.658

.54

\section{Goal 3: Measure Student Self-Assessment Gains in Science Literacy in General Education Courses}

To explore the implementation of the SCILIT self-assessment, our third goal had two parts: 1) to determine if we could measure student gains in student self-assessed science literacy during an academic quarter using the eight-item SCILIT instrument and 2) to compare students' self-assessed science literacy to instructors' evaluation of students' academic proficiency and science literacy in a set of courses across disciplines, including interdisciplinary courses. For part 1, to explore whether students gained in self-reported science literacy through the term, 162 students enrolled in three science courses in winter 2013 taught by graduate student and faculty teaching teams (a convenience sample of students in courses affiliated with the program consisting of one section each of two interdisciplinary courses: chemistry/physics and biology/chemistry and one single subject course: biology) completed pre- and post-SCILIT self-assessments. We computed a pre-course (beginning of term) SCILIT score and post-course (end of term) SCILIT score by averaging the responses on the eight science literacy self-assessment items. In this initial exploration, we found a significant, but modest increase in students' self-reported science literacy from the start of the term $(M=3.68$; $S D=$ $0.56)$ to the end of the term $(M=3.83$; $S D=0.55)$, but the effect size was small indicating these gains were relatively small (paired-sample $t(161)=3.44, p=0.001, d=0.27$ ).

For part 2, to explore whether students' end-of-term self-assessments related to their individual instructors' rating of demonstrated academic proficiency and science literacy, we had students complete an end of term summative assessment (e.g. final exam) designed and scored by their instructors based on a previous instructor rating protocol (Beghetto \& Baxter, 2012). Without a separate validated trans-disciplinary instrument for comparison, we chose to look at how typical instructor-designed summative assessments related to student self-reported science literacy, as a 
comparison to ways students would normally be evaluated and graded in program affiliated courses. The summative assessments were written by the faculty and varied between courses so as to have direct alignment to specific course learning outcomes. Additionally, faculty focused on aligning and designing an assessment to measure at least one of the eight SCILIT self-assessment statements that best fit the course content. Faculty were asked for an end-of-term evaluation to "Create ONE question that is part of an in-class activity, homework assignment, quiz, or exam that includes reference to one of the eight science literacy behaviors within the question. This may be a written response to a question, a concept map, or other activity. Have your students answer this question." Faculty each developed a question that was best aligned to the learning environment they had created for students and designed to measure students' learning of science literacy as taught in each particular course.

In spring 2014 for the various course summative assessment questions, students: 1) read an article from a popular science magazine, 2) read a real-life case study, 3) read excerpts from newspapers, 4) interpreted data from graphs, 5) imagined a scenario in which they were asked to explain science to a novice or interpret a scientific representation on TV, or 6) watched a science documentary. Students then answered questions developed by faculty such as: 1) writing descriptions of the reading, 2) interpreting data and graphs, and/or 3) drawing numeric and graphical representations. To align with the course learning objectives, some of the summative assessments were presented in typical final exam format, others students completed during an in-class activity, and some were completed as part of a final take-home final exam.

Twelve faculty and graduate students (one astronomy, four biology, five geology, and two physics) rated answers to the questions for both academic proficiency and science literacy. Faculty received training from the authors on using the five-point scale rubric to score academic and science literacy proficiency prior to implementation and practiced scoring with mock-up assessments (Beghetto \& Baxter, 2012). Faculty then provided training to their graduate student teams. Raters scored assignment answers from their course and discipline (e.g., biology instructors scored biology assignments). If more than one person evaluated the summative assessment responses, rating teams worked together scoring a small sample to establish consistency and then independently scored a portion of the students' work.

We looked at the relationship between instructor ratings of summative assessment answers and students' survey responses on the SCILIT self-assessment both of which were completed by 576 students. We included only students who had completed the SCILIT self-assessment (part 2), had an instructor rating on academic proficiency and science literacy, and were enrolled in a course with at least 30 students. The resulting dataset included students drawn from seven courses representing four subjects: astronomy $(\mathrm{n}=101,17.5 \%)$, biology $(\mathrm{n}=166,28.8 \%)$, geology $(\mathrm{n}=252,43.8 \%)$, and physics $(\mathrm{n}=57,9.9 \%)$. The majority of students reported their gender as female $(\mathrm{n}=324,55.6 \%)$ and their ethnicity as Caucasian or white $(\mathrm{n}=415,71.2 \%)$.

In an effort to evaluate students' self-rated science literacy, we had students respond to a survey that included items measuring these behaviors. We then calculated an average SCILIT score for all students based on their response to the eight items represented in Table $3(M=3.82, S D=54$, range 2 to 5$)$. We then had instructors use a five-point scale $(1=$ lowest, $5=$ highest $)$ to rate the academic proficiency of the student response to the course assessment $(M=3.47$, $S D=1.17, n=$ 576) which was tied to the course grading rubrics for summative assessments directly related to course scientific content and learning objectives.

Instructors also used a five-point scale $(1=$ lowest, $5=$ highest $)$ to rate the science literacy proficiency of the associated SCILIT behavior(s) included in the summative assessment $(M=3.34$, $S D=1.18, n=576$ ). For example, after reading an article and answering questions a student might correctly answer questions about the science content (e.g. scale point of 5) but have a partially incorrect

Journal of the Scholarship of Teaching and Learning, Vol. 20, No. 2, October 2020. josotl.indiana.edu 
answer to questions about assumptions or the process of science included in the article (e.g. scale point of 3).

We conducted Pearson's correlations to explore the relationship between student self-reported science literacy and instructor-assessed science literacy or academic proficiency. There was a statistically significant but very weak, positive correlation between student self-reported science literacy and instructor-assessed science literacy $(r=.119, n=576, p=.004)$. There was also a statistically significant but very weak, positive correlation between student self-reported science literacy and instructor-assessed science academic proficiency $(r=.164, n=576, p<.001)$.

\section{Concluding Thoughts}

We elicited a science literacy definition from instructors affiliated with our program across science disciplines, and developed and implemented a student self-assessment (SCILIT) to learn how students assessed their science literacy.

We do not claim that our SCILIT definition is unique or the "best" or "correct" one or applicable to all other contexts. It grew from the initial input from our cross-disciplinary group of instructors who wanted to better understand the science literacy development of their students. While this group represents a well-rounded, experienced one, other similar efforts using a different group may elicit a different SCILIT definition. Our focus here is on the methodology developed and the initial, exploratory results it produced.

Our focus on student science literacy self-belief is particularly important in general education courses designed to empower students in scientific thinking, especially when these courses might be the last formal science instruction students received. We compared student self-assessed science literacy before and after a general education science course as well as relative to how they were rated by experts in the field. Our initial findings suggest that our eight-item SCILIT self-assessment scale has the potential to compliment other forms of assessment and help monitor students' perceptions of science literacy in our and other contexts.

Although self-assessments can serve as an important source of data - particularly when attempting to understand students' learning experiences (Ames, 1992; Stipek, 1981) - we recognize they are prone to various forms of misperception, inaccuracy, overestimation, and bias (Dunning, Heath, \& Suls, 2004). Gaps often exist between espoused beliefs (what students believe they know and can do) and actual knowledge and behaviors (Argyris \& Schon, 1974). Weak correlations observed between instructor-evaluated metrics and student-assessed science literacy may also reflect how well assignments aligned to science literacy behaviors. Future metrics could tease apart the elements of the course that lead to alignment, over-estimation, or under-estimation of ability.

Science anxiety is high, even in science courses designed for non-science majors (Udo et al., 2004). This is a factor that our affiliated faculty considered when designing courses and assessments. Science anxiety and instructor efforts to mitigate it may have led to under-estimation or overestimation of self-assessed science literacy. Future studies could examine which design or structural elements of each course lead to increasing student self-assessed science literacy, and ways in which faculty can continue to support development of student science literacy.

Even with these limitations, our project provided insights into how students perceive characteristics of science literacy in themselves, how those perceptions might change over a short time (across a term), and how those conceptions may differ from the way instructors view students' demonstrations of science literacy on courses assignments and assessments. Insights from evaluating students' views of their science literacy and relating it to academic proficiency with the course content could be helpful to instructors by revealing any divide between what instructors think they are teaching and what students are learning. Such insights could also prompt instructors to re-think their

Journal of the Scholarship of Teaching and Learning, Vol. 20, No. 2, October 2020. josotl.indiana.edu 
conceptions of science literacy, both more generally and specifically in the context of their particular courses and fields of study, and to develop new strategies to help students increase their science literacy. For example, instructors may need to provide better scaffolding for students to align their abilities with course expectations, create opportunities for students to develop more accurate selfjudgments through inclusion of self-reflection and metacognition, or more transparently align course learning objectives and assessments.

Although the focus of our work was to clarify an expert science literacy conception and develop a student science literacy SCILIT self-assessment for use in our courses at our university, our initial results have potential applications for continued classroom teaching and learning. In our courses we emphasize creating student-centered classrooms using evidence-based techniques. Teaching teams provide opportunities for students to uncover relevance of science to their everyday lives with topics such as gene therapy and information technology. Indeed, continuing to provide these types of learning environments is in line with existing research regarding ways to improve learning outcomes and student success for all students while continuing to focus on development of students' science literacy (Allen \& Tanner, 2005; Crouch \& Mazur, 2001; Freeman et al., 2014; Singer et al., 2012). We have continued to use the student SCILIT self-assessment as a framework for developing and revising student learning outcomes and assessments across courses in our program as this framework for science literacy has resonance with both our instructors and students.

Our eight-item student SCILIT self-assessment is well-aligned with two Vision and Change Core Competencies: ability to apply the process of science and ability to understand the relationship between science and society (Brewer \& Smith, 2011). The six Vision and Change competencies were specifically targeted to development of students' biological literacy. However, there are elements in each competency that are directly transferrable to other disciplines and the applicability to other contexts could be part of future work.

Our initial efforts have raised several important questions for us and for science instructors interested in this topic to explore and revisit, including:

- How might instructors continue to close the gap between their conceptions of science literacy and their students' conceptions?

- How does student self-reported science literacy compare to scores on a concept inventory of science literacy reasoning (Nuhfer et al., 2016)?

- How does student self-reported science literacy change over the course of several general education science courses?

- In what ways does the application of science literacy vary by course content, subject area, or student population?

- How might instructors best target, teach, and assess science literacy in their particular courses, subject areas, and student population?

- How might we and other instructors refine and improve upon our efforts to clarify and monitor students' science literacy?

In sum, now that we have developed an initial conception of eight science literacy behaviors with the student SCILIT self-assessment and explored the initial relationship between student selfassessed and instructor-assessed science literacy, future research should focus on further testing and refining our (and other) self-report science literacy measures. Our initial results indicate that our SCILIT self-assessment can be used across disciplines at our university. Further expansion of the SCILT self-assessment to other academic disciplines or contexts may refine the self-assessment for science instructors and researchers to identify, monitor, and support development of students' science

Journal of the Scholarship of Teaching and Learning, Vol. 20, No. 2, October 2020. josotl.indiana.edu 
literacy. In this way, developing students' science literacy can be incorporated in the broader goal of promoting science learning. We hope that by sharing our efforts aimed at clarifying what science literacy means amongst our interdisciplinary group of science instructors, others may learn from our efforts and embark on similar projects. We therefore invite science instructors to use, modify, and refine our initial methods for developing a SCILIT definition and our approaches to using such a definition through student SCILIT self-assessment.

\section{Acknowledgements}

Funding for this work was supported by a grant from the Howard Hughes Medical Institute (grant no. 52006956, Science Education Division) and also supported by funds from the University of Oregon to launch the Science Literacy Program. We thank the Center on Diversity and Community $(\mathrm{CoDaC})$ Faculty in Residence Program. We also wish to thank all of our affiliated Faculty, Graduate SLP Fellows, and Undergraduate SLP Fellows, who supported development of science literacy in undergraduate students at the University of Oregon.

\section{References}

Adams, A. E., \& Pegg, J. (2012). Teachers' enactment of content literacy strategies in secondary science and mathematics classes. Journal of Adolescent \& Adult Literacy, 56, 151-161. https://doi.org/10.1002/JAAL.00116

Allen, D., \& Tanner, K. (2005). Approaches to biology teaching and learning: From a scholarly approach to teaching to the scholarship of teaching. Cell Biology Education, 4, 1-6. https://doi.org/10.1187/cbe.04-11-0052

Ames, C. (1992). Classrooms: Goals, structures, and student motivation, Journal of Educational Psychology, 84, 261-271.

Argyris, C., \& Schon, D. A. (1974). Theory in practice: Increasing professional effectiveness. San Francisco, CA: Jossey-Bass.

Baer, J., \& McKool, S. S. (2009). Assessing creativity using the consensual assessment technique. In Handbook of assessment technologies, methods, and applications in higher education. Hershey, PA: IGI Global.

Bandura, A. (1997). Self-efficacy: the exercise of control. New York: Freeman.

Beghetto, R. A., \& Baxter, J. A. (2012). Exploring student beliefs and understanding in elementary science and mathematics. Journal of Research in Science Teaching, 49, 942-960. https://doi.org/10.1002/tea.21018

Birmingham, D., \& Barton, A. C. (2013). Putting on a green carnival: Youth taking educated action on socioscientific issues. Journal of Research in Science Teaching, 51, 286-314. https://doi.org/10.1002/tea.21127

Brewer, C. A., \& Smith, D. (2011). Vision and change in undergraduate biology education: a call to action. American Association for the Advancement of Science, Washington, DC.

Bryant, F. B., Kastrup, H., Udo, M., Hislop, N., Shefner, R., \& Mallow, J. (2012). Science anxiety, science attitudes, and constructivism: A Binational study. Journal of Science Education and Technology. https://doi.org/10.1007/s10956-012-9404-x

Buehl, M. M., \& Alexander, P. A. (2005). Motivation and performance differences in students' domain-specific epistemological belief profiles. American Educational Research Journal, 42, 697-726. https://doi.org/10.3102/00028312042004697

Choi, K., Lee, H., Shin, N., Kim, S.-W., \& Krajcik, J. (2011). Re-conceptualization of scientific

Journal of the Scholarship of Teaching and Learning, Vol. 20, No. 2, October 2020.

josotl.indiana.edu 
literacy in South Korea for the 21st century. Journal of Research in Science Teaching, 48, 670-697. https://doi.org/10.1002/tea.20424

Coil, D., Wenderoth, M. P., Cunningham, M., \& Dirks, C. (2010). Teaching the process of science: Faculty perceptions and an effective methodology. CBE Life Sciences Education, 9, 524-535. https://doi.org/10.1187/cbe.10-01-0005

Costello, A. B., \& Osborne, J. W. (2005). Best practices in exploratory factor analysis: Four recommendations for getting the most from your analysis. Practical Assessment, Research, \& Evaluation, 10. Retrieved from http://www.pareonline.net/pdf/v10n7.pdf (accessed 20 September 2018).

Crouch, C. H., \& Mazur, E. (2001). Peer Instruction: Ten years of experience and results. American Journal of Physics, 69, 970. https://doi.org/10.1119/1.1374249

Dalkey, N. C., \& Helmer, O. (1963). An experimental application of the Delphi method to the use of experts. Management Science, 9, 458-467.

Deboer, G. E. (2000). Scientific literacy: Another look at its historical and contemporary meanings and its relationship to science education reform. Journal of Research in Science Teaching, 37, 582601. https://doi.org/10.1002/1098-2736(200008)37:6<582::AID-TEA5>3.0.CO;2-L

Dunning, D., Heath, C., \& Suls, J. M. (2004). Flawed self-assessment implications for health, education, and the workplace. Psychological Science in the Public Interest, 5, 69-106. https://doi.org/10.1111/j.1529-1006.2004.00018.x.

Duschl, R. A., Schweingruber, H. A., \& Shouse, A. (2007). Taking science to school: Learning and teaching science in grades K-8. (R. A. Duschl, H. A. Schweingruber, \& A. Shouse, Eds.). Washington DC: National Academies Press.

Falk, J. H., \& Needham, M. D. (2013). Factors contributing to adult knowledge of science and technology. Journal of Research in Science Teaching, 50, 431-452. https://doi.org/10.1002/tea.21080

Freeman, S., Eddy, S. L., McDonough, M., Smith, M. K., Okoroafor, N., Jordt, H., \& Wenderoth, M. P. (2014). Active learning increases student performance in science, engineering, and mathematics. Proceedings of the National Academy of Sciences, 111, 8410-8415. https://doi.org/10.1073/pnas.1319030111

Goldsmith, S. T., Trierweiler, A. M., Welch, S. A., Bancroft, A. M., Bargen, Von, J. M., \& Carey, A. E. (2013). Transforming a university tradition into a geoscience teaching and learning opportunity for the university community. Journal of Geoscience Education, 61, 280-290.

Gormally, C., Brickman, P., \& Lutz, M. (2012). Developing a test of scientific literacy skills (TOSLS): Measuring undergraduates' evaluation of scientific information and arguments. CBE Life Sciences Education, 11, 364-377. https://doi.org/10.1187/cbe.12-03-0026

Gräber, W., Erdmann, T., \& Schlieker, V. (2001). Aiming for scientific literacy through selfregulated learning with the internet, In Science and Technology Education: Preparing Future Citizen. Proceedings of the IOSTE Symposium in Southern Europe, 1-13.

Gross, L. (2006). Scientific illiteracy and the partisan takeover of biology. PLoS biology, 4, e167. https://doi.org/10.1371/journal.pbio.0040167

Handelsman, J., Miller, S., \& Pfund, C. (2007). Scientific Teaching. Macmillan.

Harpe, S. E. (2015). How to analyze Likert and other rating scale data. Currents in Pharmacy teaching and learning, 7, $836-850$.

Hazen, R. M. (2002). Why should you be scientifically literate? ActionBioscience.org.

Hobson, A. (2003). Physics literacy, energy and the environment, Physics Education, 38(2), 1-6.

Holbrook, J., \& Rannikmae, M. (2009). The meaning of scientific literacy. International Journal of Environmental and Science Education, 4, 275-288.

Hungerford, H. R. (2009). Environmental education (EE) for the 21st Century: Where have we

Journal of the Scholarship of Teaching and Learning, Vol. 20, No. 2, October 2020.

josotl.indiana.edu 
been? Where are we now? Where are we headed? The Journal of Environmental Education, 41, 16. https://doi.org/10.1080/00958960903206773

Hurd, P. D. (1998). Scientific literacy: New minds for a changing world. Science Education, 82, 407416. https://doi.org/10.1002/(SICI)1098-237X(199806)82:3<407::AID-SCE6>3.0.CO;2-G

Jack, B. M., Lin, H.-S., \& Yore, L. D. (2014). The synergistic effect of affective factors on student learning outcomes. Journal of Research in Science Teaching, 51(8), 1084-1101. https://doi.org/10.1002/tea.21153

Jin, G., \& Bierma, T. (2013). STEM for non-STEM enhancing science literacy in large classes. Journal of College Science Teaching, 42(6), 20-26.

Joliffe, I. T. \& Cadima, J. (2016). Principal component analysis: A review and recent developments. Philosophical Transactions, Royal Society A, 374, 1 - 16.

Karsai, I., \& Kampis, G. (2010). The crossroads between biology and mathematics: The scientific method as the basics of scientific literacy. BioScience, 60, 632-638. https://doi.org/10.1525/bio.2010.60.8.9

Kohut, A., Keeter, S., Doherty, C., \& Dimock, M. (2009). Scientific achievements less prominent than a decade ago: Public praises science; scientists fault public, media. Washington, DC: The Pew Research Center

Laugksch, R. C. (2000). Scientific literacy: A conceptual overview. Science Education, 84, 71-94. https://doi.org/10.1002/(SICI)1098-237X(200001)84:1<71::AID-SCE6>3.0.CO;2-C

Lee, S., \& Roth, W.-M. (2003). Science and the " Good Citizen ": Scientific literacy communitybased. Science, Technology, \& Human Values, 28, 403-424. https://doi.org/10.1177/0162243903028003003

Lim, W., Plucker, J. A., \& Im, K. (2002). We are more alike than we think we are: Implicit theories of intelligence with a Korean sample. Intelligence, 30, 185-208. https://doi.org/10.1016/S0160-2896(01)00097-6

MacKinnon, D. W. (1964). The study of lives. New York: Atherton Press.

Marder, M. (2013). A problem with STEM. CBE Life Sciences Education, 12, 148-150. https://doi.org/10.1187/cbe.12-12-0209

McCaffrey, M. S., \& Buhr, S. M. (2008). Clarifying climate confusion: addressing systemic holes, cognitive gaps, and misconceptions through climate literacy. Physical Geography, 29, 512-528. https://doi.org/10.2747/0272-3646.29.6.512

Miller, J. D. (2004). Public understanding of, and attitudes toward, scientific research: What we know and what we need to know. Public Understanding of Science, 13, 273-294. https://doi.org/10.1177/0963662504044908

Miller, J. D. (2006). Civic scientific literacy in Europe and the United States. World Association for Public Opinion Research, 17. https://doi.org/10.1088/0963-6625/7/3/001

National Academies of Sciences, Engineering, and Medicine. (2016). Science Literacy: Concepts, Contexts, and Consequences. Washington, DC: The National Academies Press. https//doi.org/10.17226/23595.

National Center for Education Statistics. (2012). The Nation's Report Card: Science in Action: Hands-On and Interactive Computer Tasks From the 2009 Science Assessment, 1-24.

National Research Council. (1996). National science education standards. Washington, DC: The National Academies Press.

National Research Council. (2013). Next Generation Science Standards: For states, by states. Washington, DC: The National Academies Press.

National Science Board. (2012). Science and Engineering Indicators 2012. Arlington VA: National Science Foundation (NSB 12-01).

Nuhfer, E. B., Cogan, C. B., Kloock, C., Wood, G. G., Goodman, A., Delgado, N. Z., \& Wheeler,

Journal of the Scholarship of Teaching and Learning, Vol. 20, No. 2, October 2020.

josotl.indiana.edu 
C. W. (2016). Using a concept inventory to assess the reasoning component of citizen-level science literacy: Results from a 17,000-student study. Journal of microbiology \& biology education, 17(1), 143. https://doi.org/10.1128/jmbe.v17i1.1036

Olson, S., \& Riordan, D. G. (2012). Engage to Excel: Producing One Million Additional College Graduates with Degrees in Science, Technology, Engineering, and Mathematics. Report to the President. Executive Office of the President.

Osborne, J., Simon, S., \& Collins, S. (2003). Attitudes towards science: A review of the literature and its implications. International Journal of Science Education, 25, 1049-1079. https://doi.org/10.1080/0950069032000032199

O'Connor, B. P. (2000). SPSS and SAS programs for determining the number of components using parallel analysis and Velicer's MAP test. Behavior Research Methods, Instruments, \& Computers, 32, 396-402.

Parkinson, J., \& Adendorff, R. (2004). The use of popular science articles in teaching scientific literacy. English for Specific Purposes, 23, 379-396. https://doi.org/10.1016/j.esp.2003.11.005

Pellegrino, J.W. \& Hilton, M. L. (Eds.). (2012). Education for life and work: developing transferable knowledge and skills in the 21st century. Washington, DC: The National Academies Press.

PISA, P. F. I. S. A. (2006). Assessing scientific, reading and mathematical literacy, 1-188.

Porter, J. A., Wolbach, K. C., Purzycki, C. B., Bowman, L. A., Agbada, E., \& Mostrom, A. M. (2010). Integration of information and scientific literacy: Promoting literacy in undergraduates. CBE Life Sciences Education, 9, 536-542. https://doi.org/10.1187/cbe.10-010006.

Scearce, C. (2007). Scientific literacy. Proquest Discovery Guide.

Schweingruber, H., Keller, T., \& Quinn, H. (Eds.). (2012). A framework for K-12 science education: Practices, crosscutting concepts, and core ideas. National Academies Press.

Singer, S. R., Nielsen, N.R. \& Schweingruber, H.A. (Eds). (2012). Discipline-based education research: Understanding and improving learning in undergraduate science and engineering. Washington, DC: The National Academies Press.

Stage, E. K., Asturias, H., Cheuk, T., Daro, P. A., \& Hampton, S. B. (2013). Opportunities and challenges in next generation standards. Science, 340, 276-277. https://doi.org/10.1126/science.1234011

Steel, B. S., Smith, C., Opsommer, L., Curiel, S., \& Warner-Steel, R. (2005). Public ocean literacy in the United States. Ocean \& Coastal Management, 48, 97-114.

Sternberg, R. J. (1985). Implicit theories of intelligence, creativity, and wisdom. Journal of Personality and Social Psychology, 49, 607. http://dx.doi.org/10.1037/0022-3514.49.3.607

Stipek, D. J. (1981). Children's perceptions of their own and their classmates' ability. Journal of Educational Psychology, 73, 404.

Udo, M. K., Ramsey, G. P., \& Mallow, J. V. (2004). Science Anxiety and Gender in Students Taking General Education Science Courses. Journal of Science Education and Technology, 13(4), 435-446.

Witte, D., \& Beers, K. (2003). Testing of chemical literacy (Chemistry in context in the Dutch National Examinations). Chemical Education International, AN-3, 1-15. 